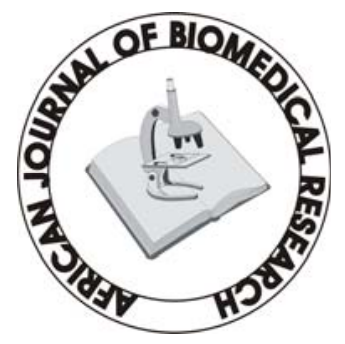

Full-text available at http://www.ajbrui.com http://www.bioline.br/md http://www.ajol.com

Received:

December 2005

Accepted (Revised): July 2006

Published

September, 2006
Full Length Research Article

\section{Reproductive Tract Morphometry and Some Haematological Characteristics of Female Rabbits Fed Pawpaw Peel Meal Based Diets}

\author{
I.I. Bitto*, J.A, Arubi and A.A. Gumel \\ Department of Animal Breeding and Physiology, \\ University of Agriculture, Makurdi, \\ Makurdi-. Nigeria
}

\section{ABSTRACT}

16 female grower rabbits were randomly assigned to any of 4 isonitrogeneous and iso-caloric diets containing 0\%, 10\%, 20\% and 30\% pawpaw meal (PPM) such that to each dietary treatment were 4 does. After 7 weeks of ad libitum feeding, all the animals were sacrificed and evaluated for reproductive tract morphometry and some haematological characteristics. The results showed similarities $(P>0.05)$ between the diets for all the parameters evaluated. The results suggest that dietary PPM up to 30\% level of inclusion may support normal body functions and the physiology of reproduction in female rabbits. (Afr. J. Biomed. Res. 9: 199 - 204)

Keywords: Pawpaw peels, haematology, reproductive tract, morphometry

*Address for Correspondence (e-mail Address): sibittos@yahoo.com

Abstracted by:

African Index Medicus (WHO), CAB Abstracts, Index Copernicus, Global Health Abstracts, Asian Science Index, Index Veterinarius, Bioline International , African Journals online 


\section{INTRODUCTION}

The ability of rabbits to convert forage crop residues and agro-industrial by-products more efficiently into meat than most other livestock (Aduku and Olukosi, 1990, Fielding, 1991) has not been applied much beyond research in the country. It is hoped that many of the unconventional feed stuff now being tested in practical diets for rabbits will soon become popular with rabbit farmers just like Tridax procumbens, a popular forage which is used in many parts of the guinea savannah as a sole diet for rabbits. Tridax is however seasonal in the guinea savannah as the practice of "bush burning" by hunters destroys much of the vegetation during the dry season.

The pawpaw plant (Carica Papaya Linn) which stands about $4-5 \mathrm{~m}$ tall on the average but could reach $10 \mathrm{~m}$ in height always survives the "bush fire" as it is grow mostly around homes. Parts of the pawpaw plant have been reported to be rich in nutrients (Oyenuga, 1968; Aduku, 1988; Nakasone and Paul, 1998) and are suitable for the feeding of rabbits especially, in the dry season. The latex in all parts of the pawpaw plant however contains a high percentage of papain- a proteolytic enzyme used in several industries. Papain however has been implicated in reproductive disorders in both male and female animals (Gwatkin, 1964; Grag, et al 1970; Egbunike et al, 2000) and shown to significantly decrease the absolute and relative weights of the liver in rabbits (Bitto and Gemade, 2001). Feeding pawpaw parts therefore must be balanced with an assessment of possible effects of residual papain in processed or fresh pawpaw parts on the physiology of reproduction in the sexes. The current lack of information on reproductive tract morphometry and the hematology of female rabbits fed pawpaw parts therefore necessitated this work.

\section{MATERIALS AND METHODS}

Location: This study was conducted at a standard Rabbitary (approved for research by the Department of Animal Production, University of Agriculture Makurdi) at the Federal Housing Authority Estate Makurdi, Nigeria. Makurdi is located at latitude $7^{0} 14 \mathrm{~N}$ and longitude $8^{0} 21 \mathrm{E}$ with an annual rain fall ranging from $1270-1397 \mathrm{~mm}$ and a temperature range of $21^{0} \mathrm{C}-42^{0} \mathrm{c}$.

Animals and Management: 16 grower rabbits of mixed breeds (Chinchilla x California x Newzealand White) between the ages of 9and 11 weeks with a mean initial weight of $1,200 \mathrm{~g}$ were used for this study. They were housed in individual cages measuring $1.5 \mathrm{~m} \mathrm{x} 1 \mathrm{~m} \mathrm{x} 1 \mathrm{~m}$ with corrugated roofing sheets and wire mesh floor with wooden frames. They were fed a maize based concentrate diet for a week of acclimatization with cool clean drinking water supplied always before the commencement of experimental feeding.

Pawpaw Peels: Unripe pawpaw fruits were obtained from Gboko, Otukpo and Makurdi towns in Benue State, Nigeria. The peels were carefully removed form the pulp immediately after harvest and sun dried for 7 consecutive rain free days and there after ground for incorporation into the test diets as pawpaw peel meal (PPM).

Experimental Diets: 4 isocaloric and isonitrogenous diets were compounded with diet I (control) containing no PPM while diets 2,3, and 4 contained $10 \%, 20 \%$ and 30\% PPM respectively. A completely randomized design was used to assign the animals to the experimental diets such that there were 4 does on each diet. The animals were fed the diets ad libitum with cool clean drinking water supplied always. The does were weighed individually weekly. The proximate compositions of the experimental diets were determined by the A.O.A.C (1990) method. The does were fed the test diets for 7 weeks.

Sampling: After 7 weeks of feeding, all the animals were starved for 12 hours and thereafter sacrificed by stunning and decapitation.

Haematological Analysis: Blood samples were collected at slaughter into clean dry test tubes containing a pinch of an anticoagulant - Ethylene diamine tetra acetic acid (EDTA) for haemotological analysis. All haematological parameters were evaluated as earlier fully described by Bitto and 
Gemade (2001).

Reproductive tract morphometry: Each animal was dissected immediately after slaughter and the reproductive tract obtained intoto, trimmed free of fat and adhering connective tissue before morphometric analysis. The weight of each reproductive tract was taken intoto after which each ovary was carefully removed from its ovarian bursa at the end of its infudibulum. The infundibulum was next removed followed by the oviduct. The uterine horn was then taken from the end of the two cervixes to the rosette projection of the uterotubal junction. Morphometric evaluations were done using highly sensitive digital balances while linear measurements were taken with well-calibrated rules.

Statistical Analysis: Data were subjected to the one way analysis of variance (ANOVA) using the completely randomized design as outlined by Steel and Torrie (1980).

\section{RESULTS AND DISCUSSION}

The gross and chemical compositions of the diets and PPM are shown in Tables 1 and 2 respectively, while the effects of PPM on reproductive tract morphometry are summarized in Tables 3 and 4 . PPM had no effect $(\mathrm{P}>0.05)$ on the morphometric characteristics of the reproductive organs and their derivations from body weight. Even though there is a lack of data in the literature on the morphometric characteristics of the reproductive organs of female rabbits with which our results could be compared, the non effect of diet on reproductive tract morphometry obtained in this study suggests that the development of the reproductive organs, reproductive processes and perhaps fertility may not be affected when PPM is included in the diets of female rabbits up to a level of $30 \%$. Being that uterine weight increase in rodents has been used as a bioindicator of the presence of estrogens (Hafez, 1980), further work establishing endogenous levels of estrogens when female rabbits are fed PPM is required. Also, going by the parameters investigated in the present study, the implication of papain in reproductive disorders in the mouse (Gwatkin, 1964) and in the rat (Grag et al, 1970) are at variance with our results.

Table 1:

Composition of the Experimental Diets (\%)

\begin{tabular}{lllll}
\hline Ingredients & $\mathbf{1 ( 0 \% )}$ & $\mathbf{2 ( 1 0 \% )}$ & $\mathbf{3 ( 2 0 \% )}$ & $\mathbf{4 ( 3 0 \% )}$ \\
\hline Maize & 30.16 & 33.39 & 37.66 & 41.43 \\
\hline $\begin{array}{l}\text { Soyabean } \\
\text { meal }\end{array}$ & 28.12 & 22.67 & 17.19 & 11.81 \\
\hline Rice offals & 35.32 & 27.54 & 18.75 & 10.36 \\
\hline $\begin{array}{l}\text { Pawpaw } \\
\text { peels }\end{array}$ & - & 10 & 20 & 30 \\
\hline $\begin{array}{l}\text { Vitamin } \\
\text { premix }\end{array}$ & 0.5 & 0.5 & 0.5 & 0.5 \\
\hline Palm oil & 1 & 1 & 1 & 1 \\
\hline Bone meal & 4 & 4 & 4 & 4 \\
\hline Methionine & 0.4 & 0.4 & 0.4 & 0.4 \\
\hline Salt & 0.5 & 0.5 & 0.5 & 0.5 \\
\hline Total & 100 & 100 & 100 & 100 \\
\hline
\end{tabular}

Table 2:

The Chemical Composition of the Experimental Diets and Pawpaw peel meal (\%)

\begin{tabular}{|l|l|l|l|l|l|}
\hline Parameters & $\mathbf{1 ( 0 \% )}$ & $\mathbf{2 ( 1 0 \% )}$ & $\mathbf{3}(\mathbf{2 0 \%})$ & $\mathbf{4}(\mathbf{3 0 \%})$ & PPM** \\
\hline Dry matter & 98.50 & 97.98 & 97.87 & 97.87 & 97.20 \\
\hline Crude protein & 20.25 & 20.94 & 18.38 & 17.44 & 17.50 \\
\hline Crude fibre & 19.40 & 17.69 & 15.18 & 12.94 & 13.30 \\
\hline Ether extract & 11.20 & 12.67 & 10.47 & 11.71 & 8.75 \\
\hline Ash & 13.82 & 12.91 & 11.70 & 11.70 & 9.10 \\
\hline M.E (Kcal/kg)* & $\mathbf{2 8 5 0 . 4 6}$ & $\mathbf{2 9 9 2 . 6 0}$ & $\mathbf{3 0 1 2 . 4 0}$ & $\mathbf{3 0 4 1 . 6 6}$ & $\mathbf{3 0 7 3 . 0 0}$ \\
\hline
\end{tabular}

- $\quad$ = Calculated from Pauzenga (1985); ** =Paw paw peel meal 
Table 3:

The effect of pawpaw peel meal on female reproductive tract morphometry (mean \pm s.e.m)*

\begin{tabular}{lllll}
\hline Parameters & $\mathbf{1 ( 0 \% )}$ & $\mathbf{2 ( 1 0 \% )}$ & $\mathbf{3 ( 2 0 \% )}$ & $\mathbf{4 ( 3 0 \% )}$ \\
\hline Body weight (g) & $1383 \pm 116.91$ & $1600 \pm 94.39$ & $1500 \pm 108.14$ & $1550 \pm 23.60$ \\
\hline Weight of tract (g) & $2.24 \pm 0.0659$ & $3.40 \pm 0.77$ & $1.62 \pm 0.38$ & $1.94 \pm 0.66$ \\
\hline Paired ovary weight (g) & $0.229 \pm 0.022-$ & $0.294 \pm 0.036$ & $0.234 \pm 0.016$ & $0.119 \pm 0.043$ \\
\hline Paired infundibulum Weight (g) & $0.12 \pm 0.025$ & $0.101 \pm 0.023$ & $0.154 \pm 0.19$ & $0.124 \pm 0.038$ \\
\hline Paired uterine horn weight (g) & $0.64 \pm 0.232$ & $1.33 \pm 0.343$ & $0.55 \pm 0.076$ & $0.97 \pm 0.043$ \\
\hline Cervix weight (g) & $0.49 \pm 0.152$ & $0.58 \pm 0.213$ & $0.25 \pm 0.042$ & $1.097 \pm 0.409$ \\
\hline Vagina weight (g) & $0.58 \pm 0.199$ & $0.93 \pm 0.223$ & $0.46 \pm 0.215$ & $0.36 \pm 0.076$ \\
\hline Paired oviduct Weight (g) & $0.122 \pm 0.37$ & $0.196 \pm 0.023$ & $0.109 \pm 0.031$ & $0.183 \pm 0.074$ \\
\hline Width of uterine horn (cm) & $0.933 \pm 0.054$ & $1.067 \pm 0.152$ & $0.933 \pm 0.027$ & $0.90 \pm 0.180$ \\
\hline Length of cervixes & $0.87 \pm 0.196$ & $1.37 \pm 0.191$ & $0.92 \pm 0.027$ & $0.87 \pm 0.189$ \\
\hline Length of ovary (cm) & $1.90 \pm 0.163$ & $1.73 \pm 0.089$ & $2.27 \pm 0.348$ & $0.90 \pm 0.189$ \\
\hline Length of oviduct (cm) & $6.00 \pm 0.794$ & $9.20 \pm 0.601$ & $8.73 \pm 0.04$ & \\
\hline Length of uterine horn (cm) & $8.07 \pm 0.409$ & $6.40 \pm 2.130$ & $10.83 \pm 0.34$ & $0.87 \pm 160 \pm 0.191$ \\
\hline
\end{tabular}

sem $=$ standard error of mean: $*=\quad(P>0.05)$

Table 4: Derivations from reproductive tract morphometry based on body weight (mean \pm s.e.m)*

\begin{tabular}{lllll}
\hline Parameters & $\mathbf{1 ( 0 \% )}$ & $\mathbf{2 ( 1 0 \% )}$ & $\mathbf{3 ( 2 0 \% )}$ & $\mathbf{4 ( 3 0 \% )}$ \\
\hline Vagina & $0.039 \pm 0.012$ & $0.057 \pm 0.012$ & $0.029 \pm 0.012$ & $0.066 \pm 0.038$ \\
& & & & $0.023 \pm 0.011$ \\
\hline Cervixes & $0.033 \pm 0.009$ & $0.035 \pm 0.011$ & $0.017 \pm 0.002$ & $0.009 \pm 0.002$ \\
\hline Paired Infundibulum & $0.009 \pm 0.002$ & $0.006 \pm 0.001$ & $0.010 \pm 0.001$ & $0.012 \pm 0.005$ \\
\hline Paired & & & $0.007 \pm 0.002$ & $0.008 \pm 0.003$ \\
\hline Paired oviduct & $0.008 \pm 0.002$ & $0.012 \pm 0.001$ & $0.015 \pm 0.002$ & $0.063 \pm 0.026$ \\
\hline Paired uterine horn & $0.043 \pm 0.014$ & $0.019 \pm 0.003$ & $0.036 \pm 0.003$ & \\
\hline
\end{tabular}

s.e.m $=$ standard error of mean; $*=(P>0.05)$

Table 5: The effect of pawpaw peel meal on the haematology of grower female Rabbits (means \pm sem)*

\begin{tabular}{|c|c|c|c|c|}
\hline Parameters & $1(0 \%)$ & $2(10 \%)$ & $3(20 \%)$ & $4(30 \%)$ \\
\hline (g/dl) & $7.86 \pm 0.65$ & $7.55 \pm 0.43$ & $6.80 \pm 0.93$ & $6.64 \pm 0.84$ \\
\hline $\operatorname{PCV}(\%)$ & $24 \pm 1.17$ & $23 \pm 1.36$ & $20 \pm 1.36$ & $20 \pm 1.85$ \\
\hline WBC $\quad\left(\mathrm{X} 10^{3} / \mathrm{mm}\right)$ & $3.13 \pm 0.05$ & $3.97 \pm 0.09$ & $3.1 \pm 0.07$ & $3.56 \pm 0.79$ \\
\hline $\operatorname{MCV}\left(\mu^{3} / m\right)$ & $68.00 \pm 0.96$ & $65.7 \pm 0.58$ & $66.66 \pm 84$ & $66.66 \pm 84$ \\
\hline $\mathrm{MCH}$ & $22.45 \pm 0.76$ & $21.57 \pm 0.61$ & $22.66 \pm 0.40$ & $22.13 \pm 0.73$ \\
\hline $\mathrm{MCHC}$ & 32.750 .95 & $32.82 \pm 1.20$ & $34.00 \pm 0.86$ & $33.20 \pm 100$ \\
\hline
\end{tabular}

SEM = Standard error of means; $\mathrm{Hb}=$ haemoglobin ; $P C V=$ packed cell volume; $W B C=$ white blood cell count ; $M C V=$ mean corpuscular volume, $\mathrm{MCH}=$ mean corpuscular haemoglobin, $\mathrm{MCHC}=$ mean corpuscular haemoglobin concentration 
It is hard to tell if this disparity is due to species differences or due to the concentration of papain that could induce such disorders (as we could not evaluate the papain concentrations of the diets). It is hoped that an analysis of the papain concentration in pawpaw peels and the test diets will provide a better understanding of the safe levels of inclusion of PPM in the diets of female rabbits.

The non effect of diet on the haematological characteristics of female rabbits obtained in this study is in agreement with the earlier report of Bitto and Gemade (2001) in male rabbits fed PPM. $\mathrm{HB}, \mathrm{PCV}$, and $\mathrm{WBC}$ values in female rabbits in the present study were however generally lower than corresponding values reported for male rabbits fed PPM (Bitto and Gemade, 2001). This disparity may be due to differences in sex and age of animals, as sex and age (which differed between the two reports) are among the factors reported to be responsible for variations in haematological vales of rabbits (Mitruka and Rawnsley, 1977). Laird et al (1970) earlier reported significant effects of age on some haematological parameters in rabbits as well as significantly higher $\mathrm{Hb}$ and hematocric values in males. This probably explains the lower values of $\mathrm{Hb}$ and PCV in female rabbits fed PPM in the present study compared to males fed PPM in an earlier report (Bitto ad Gemade, 2001). The lower leucocyte counts in female rabbits in the present study compared to males fed PPM (Bitto and Gemade, 2001) and normal values for males and females elsewhere (Mitruka and Rawnsley, 1977) may in addition to other factors (age, sex and nutrition) be due to diurnal variation which has been reported to considerably influence leucocyte count (Mitruka and Rawnsley, 1977).

MCV, MCH and MCHC values obtained in this study were however comparable to normal values reported for both male and female rabbits (Mitruka and Rawnsley, 1977). The red blood cells in these animals could therefore be classified as normochromic, further confirming the suitability of PPM for the feeding of female rabbits in the humid tropics.
Conclusion: We conclude from the results of this study that even though PPM up to $30 \%$ level of inclusion may support growth, the development of the reproduce tract and probably other body activities in female rabbits, further work on the effect of PPM on other aspects of the physiology of reproduction like endocrinology, the histometry of the reproductive organs and the fertility of these animals may be required for the establishment of optimum levels of PPM inclusion in the diets of female rabbits.

\section{REFERENCES}

Aduku, A.O. (1988). Feeding value of tropical forges and dry season feeding of rabbits. A paper presented at the national rabbit production seminar organized by AERLS, Ahmadu Bello University, Zaria. Aug. 30-Sept. 1 (1988).

Aduku, A.O. and Olukosi, J.O. (1990). Rabbit management in Tropics. Living books Series. GU Publications, Abuja, Nigeria.

Bitto, I.I. and Gemade, M. (2001). Preliminary investigations on the effect of Pawpaw peel meal on growth, visceral organ and endocrine gland weights, testicular morphometry and the haematology of male rabbits, Global J.P. \& Appl. Sci. 7(4); $611-625$.

Cheeke, P.R. (1984). Rabbit nutrition and feeding: recent advances and future perspective, J. Appl. Rabbit Res. 7(1): 31 - 37.

Egbunike, G.N; Sadiku, M.O. and Okebiorun O.E. (2000). Sperm production and related phenomenon in rats fed diets containing pawpaw peels, seed and leaves. Trop. J. Anim. Sci. 3(20. $77-84)$.

Fielding, D. (1991). The Tropical Agriculturist Macmillan Press Ltd. London Pp 2, 18, 30.

Grag, S.K.; Saksena, S.K and Chaudhury, R.R. (1970). Antifertility screening of plant parts. VI. Effect of five indigenous plants on early pregnancy in albino rats. Indian J. Med. Res. 58: 1258.

Gwatkin, R.B.L. 1964. Effects of enzymes and acidity on the zona pellucida of the mouse egg before and after fertilization. J. Reprod. Fert. 7:99. Hafez, E.S.E (1980). Laboratory Animals. In 
Reproduction in farm Animal. E.S.E. Hafez, (Ed.) Lea of Febiger, Philadelphia. Pp 409 - 422.

Laird, C.W., Fox, R.R, Mitchell, B.P., Blau, E.M. and Schultz H.S (1970). Effects of strain and age on some hematological parameters in the rabbit. Amer. J. Physiol. 218: 1613 - 1617.

Mitruka, B.M. and Rawnsley, H.M. (1977). Clinical, Biochemical and Haematological Reference values in Normal Experimental Animals. Masson Publishing USA inc. New York, USA. PP82 - 144.

Nakasone, H.Y. and Paul, R.E. (1998). Tropical fruits. Biddled Ltd. Guild Ford and Kings. PP 239 $-268$.

NAPRI (1998). Livestock production in Nigeria: News Letter - National Animal Production Research Institute, Ahmadu Bello University, Shaki - Zaria. June 1998 PP1

Oyenuga, V. A. (1968). Nigeria's foods and feeding stuffs: their chemistry and nutritive value.
University of Ibadan Press, Ibadan.

Pauzenga, U. 1985. Feeding Parent stock. Zootecnica International. December 1985. PP. 2224.

Samson, J.A (1986). Tropical fruits. Published in the United State with Wiley and Sons Inc. $6053^{\text {rd }}$ Avenue New York.

Steel, R.G. D and Torrie, J.H. (1980). Principles and Procedures of Statistics: A Biometrical Approach. $2^{\text {nd }}$ Ed. Mc Graw - Hill Book Co. Inc. New York.

Taiwo, A.A; Adejuyigbe, A.D.; Adebowale, E.A; Oshotan, J.S. and David, O.O. (2005). Performance and nutrient digestibility of weaned rabbits fed forages supplemented with concentrate. Nig. J. Anim. Prod. 32(1): $74-78$. 